\title{
PERAN PEMERINTAH DAERAH DALAM PENGATURAN PERTAMBANGAN RAKYAT
}

\author{
M. Saleh, Kafrawi, Abdul Khair \& Sarkawi \\ Fakultas Hukum Universitas Mataram \\ Lombok, NTB, Indonesia \\ Email : msalehfhunram@gmail.com \\ Email : kafrawifh@gmail.com \\ Email : abdulkhair@unram.ac.id \\ Email : sarkawishmh@gmail.com
}

\begin{abstract}
ABSTRAK
Kekayaan sumber daya alam yang ada setidaknya mampu menopang perekonomian suatu negara, tidak terkecuali juga bagi pemerintah daerah. Salah satu kekayaan alam yang dimiliki tersebut adalah kekayaan alam berupa tambang mineral, batubara dan gas bumi. Kegiatan pertambangan yang ada hampir disemua daerah telah mampu membawa perubahan yang signipikan bagi masing-masing daerah, baik itu dalam bentuk penerimaan kas daerah, peningkatan ekonomi daerah, pembangunan pisik dan sebagainya. Tujuan penelitian ini untuk mengetahui Peran Pemerintah Daerah Dalam Pengaturan Pertambangan Rakyat. Metode yang digunakan dalam penelitian ini metode normatifempiris, dengan menggunakan pendekatan peraturan perundang-undangan, pendekatan konsep dan pendekatan empirik. Hasil penelitian, kebijakan pengelolaan tambang rakyat yang dilakukan oleh pemerintah daerah diperuntukkan untuk mampu meningkatkan taraf hidup masyarakat setempat dan masyarakat pada umumnya. Aktipitas pertambangan rakyat tersebut seyogyanya tetap menjaga kelangsungan hidup dan keamanan ekosistem lain yang terkait dengan tambang rakyat tersebut. Di samping itu, dalam penerapan kabijakan yang dilakukan oleh pemerintah daerah, hal yang penting lagi adalah peran DPRD dalam melakukan pengawasan terhadap kebijakan tersebut.
\end{abstract}

Kata Kunci: Pertambangan Rakyat; Pemerintah Daerah.

\section{ABSTRACT}

The existing natural resource wealth is at least capable of supporting the economy of a country, not least for regional governments. One of the natural resources owned is natural wealth in the form of mineral, coal and natural gas mines. Mining activities that exist in almost all regions have been able to bring significant changes to each region, both in the form of regional cash receipts, increasing the regional economy, physical development and so on. The purpose of this study was to determine the Role of Local Government in People's Mining Arrangements. The method used in this research is a normative-empirical method, using a statutory approach, conceptual approach and empirical approach. The result of the research shows that the people's mining management policies implemented by the local government are intended to be able to improve the standard of living of the local community and society in general. The people's mining activities should still maintain the survival and security of other ecosystems associated with these community mines. In addition, in implementing the policies carried out by local governments, what is more important is the role of DPRD in supervising these policies.

Keywords: People's Mining; Local Government. 


\section{A. PENDAHULUAN}

Bumi sebagai hamparan alam yang diciptakan oleh Allah SWT, Tuhan Yang Maha Esa berisi semua keperluan bagi mahluk ciptaannya. Hamparan lahan bumi ini diperuntukkan bagi kehidupan semua mahluk, sesuai dengan kodratnya masing-masing. Kekayaan alam tersebut dibagi lagi dalam dua kategori, kekayaan alam hayati dan non hayati. Masing-masing kekayaan alam tersebut memiliki fungsi dan peran masing-masing dalam siklus kehidupan manusia dan mahluk lainnya.

Kekayaan alam non hayati sebagai bagian sumberdaya alam yang keberadaannya telah membawa perubahan besar bagi perkembangan alam dan manusia. Semua negara yang ada berlomba-lomba untuk melakukan riset untuk selanjutnya dipergunakan bagi kemakmuran rakyatnya. Bumi, air dan kekayaan alam yang terkandung didalamnya dipergunakan untuk kemajuan dan kemaslahatan hidup untuk semua mausia. Salah satu bagian kecil dari kekayaan alam tersebut adalah pertambangan. Kegiatan pertambangan yang dikelola negara dan pemerintah daerah ditujukan untuk kemajuan pembangunan disetiap bidang, dengan sistem pembagian yang proporsional dan profesional antara pemerintah pusat dan pemerintah daerah.

Untuk menujung kegiatan tersebut, pemerintah pusat melakukan pengaturan terkait dengan pertambangan tersebut, salah satunya adalah dibentuknya undang-undang dalam bidang pertambangan. Pengaturan tersebut diperlukan untuk memberikan batasan pengelolaan kepada pemerintah dan pemerintah daerah dalam bidang pertambangan. Salah satu dari regulasi tersebut adalah dibentuknya undang-undang dalam bidang pertambangan, yaitu Undangundang Nomor 4 Tahun 2009 tentang Pertambangan Mineral dan Batu Bara.

Keberadaan undang-undang tersebut dijadikan sebagai acuan oleh pemeritah, khususnya bagi pemerintah daerah dalam melakukan pengelolaan pertambangan yang ada didaerah. Hal tersebut sejalan dengan konsep dan pengembangan pemerintah daerah yang diatur dalam Undang-undang Nomor 23 Tahun 2014 tentang Pemerintah Daerah. Dalam Undang-undang 23 tahun 2014, pemerintah daerah diberikan kewenangan sepenuhnya untuk melakukan penataan dan pengelolaan daearah sepenuhnya berdasarkan inisiatif dan hak asal-usul daerah masingmasing, dikecualikan terhadap hal-hal yang disebutkan dalam undang-undang tersebut.

Pemerintah daerah sebagai bagian perpanjang pemerintah pusat dalam dalam bentuk desentralisasi, dekonsentrasi dan tugas pembantuan. Salah satu kewenangan tersebut adalah pengeloaan pertambangan yang ada diaerah. Pengelolaan pertambangan tersebut dilakukan baik itu oleh BUMD, swasta mapun oleh masyarakat atau rakyat yang ada didaerah. Pemerintah daerah memiliki andil besar dalam melakukan pengelolaan pertambangan tersebut, terutama dalam hal pertambangan rakyat. Bagaimana tidak, pertambangan rakyat yang dilakukan oleh masyarakat membawa pengaruh tersendiri bagi pengembagan perekonomian bagi suatu daerah dan masyarakat diwilayahnya. Salah satunya adalah peningkatan taraf hidup dan menyerap tenaga kerja. Selain itu juga, dampak yang lain juga harus dijadikan pertimbangan, misalnya terhadap lingkungan dan lain-lain.

Dalam pengembangan dan pemanfaatan potensi sumberdaya alam tersebut, dalam rangka pelaksanaan otonomi daerah, daerah otonom sebagai pelaksana otonomi diberikan kewengan dalam melakukan pengelolaan sumberdaya alam tersebut. Pengelolaan sumberdaya yang ada pada suatu daerah tidak sekedar di hajatkan untuk meningkat penerimaan daerah semata, akan tetapi diharapkan mampu membawa kesejahteraan bagi masyarakat (dalam hal peningkatan taraf ekonomi masyarakat). Setiap kepala daerah diharapkan mampu berkereasi dan aktif dalam mengelola pertambangan rakyat tersebut, hal ini dapat dilakukan diantaranya pengaturan regulasi dalam hal pemanfaatan dan pengelolaan pertambangan yang diharapkan. Didalam pelaksanaan kebijakan pertambangan tersebut, dibutuhkan peran pengawasan yang dilakukan 
oleh legislatif daerah sebagai mitra eksekutif daerah dalam menjalankan roda pemerintahan didaerah. ${ }^{1}$

\section{B. METODE PENELITIAN}

Metode penelitian yang digunakan dalam penelitian ini adalah metode normatif-empiris. Normatifnya yaitu mengkaji norma-norma hukum yang berkaitan dengan pertambangan rakyat, sedangkan empirisnya melihat kesesuaian kondisi senyatanya yang ada dilapangan mengenai penerapan norma-norma hukum tersebut dalam bidang pertambangan rakyat ${ }^{2}$

\section{PEMBAHASAN}

\section{Konsep Umum Pertambangan Rakyat}

Istilah hukum pertambangan merupakan terjemahan dari bahasa Inggris, yaitu mining law. Hukum pertambangan adalah hukum yang mengatur tentang penggalian atau pertambangan bijih-bijih dan mineral dalam tanah. ${ }^{3}$ Definisi ini hanya difokuskan pada aktifitas atau pertambangan bijih-bijih. Penggalian atau pertambangan merupakan usaha untuk menggali berbagai potensi-potensi yang terkandung dalam perut bumi. Di dalam definisi ini juga tidak terlihat bagaimana hubungan antara pemerintah dengan subyek hukum. Padahal untuk menggali bahan tambang itu diperlukan perusahaan atau badan hukum yaang mengelolanya.

Hukum pertambangan merupakan salah satu bidang kajian hukum yang mengalami perkemabngan pesat. Hal ini dibuktikan dengan ditetapkannya berbagai peraturan perundangundangan yang mengatur tentang pertambangan. Undang-undang yang mengatur tentang pertambangan, yaitu Undag-undang Nomor 11 Tahun 1967 tentang ketentuan-ketentuan pokok pertambangan dan Undang-undang Nomor 4 Tahun 2009 tentang Pertambangan Mineral dan Batu Bara. ${ }^{4}$

Dalam definisi lain, pertambangan dikonstruksikan sebagai suatu kegiatan. Kegiatan terebut meliputi penelitian, pengelolaan, dan pengusahaan. Mineral meruapak senyawa organik yang terbentuk di alam, yang memiliki sifat fiik dan kimia tertentu serta susunan kristal teratur atau gabungannya yang membentuk batuan, baik dalam bentuk lepas atau padu. ${ }^{5}$

\section{Upaya Pemerintah Daerah Dalam Penataan Pertambangan Rakyat}

Dalam pelaksanaan otonomi daerah, pemerintah daerah diberikan kewenangan oleh undang-undang untuk mengatur dan mengurus sendiri pelaksanaan pemerintahan di daerahnya. Pelaksanaan kewenangan tersebut bukan tanpa arti, kewenangan tersebut melekat sepenuhnya

1 . M. Saleh dkk. (2015). Aspek Yuridis Terhadap Pelaksanaan Pertambangan Rakyat Berdasarkan UU No 4 Tahun 2009 (Studi Di Kab.Sumbawa Barat), Jurnal Jatiswara, v.30, Juli. hlm. 177.

2 . Amiruddin dan Zainal Asikin.(2004). Pengantar Metode Penelitian Hukum, Cetakan Kedua, Jakarta : PT. Raja Grafindo, hlm. 118.

3 . Salim HS. (2006). Hukum Pertambangan di Indonesia, Jakarta, Raja Grafindo Persada, hlm. 7.

4 . Salim HS. (2012). Hukum Pertbangan Mineral dan Batu Bara. Jakarta. Sinar Grafika. Hlm. 11.

5 . Ibid. Hlm. 15. 
pada penyelenggara pemerintahan yang ada didaerah, baik itu daerah Provinsi, Kabupaten/ maupun Kota.

Dalam hukum publik, wewenang berkaitan dengan kekuasaan. Kekuasaan memiliki makna yang sama dengan wewenang karena kekuasaan yang dimiliki oleh Eksekutif, Legislatif dan Yudikatif adalah kekuasaan formal. Kekuasaan merupakan unsur esensial dari suatu Negara dalam proses penyelenggaraan pemerintahan di samping unsur-unsur lainnya, yaitu: a) hukum; b) kewenangan (wewenang); c) keadilan; d) kejujuran; e) kebijaksanaan; dan f) kebajikan.6

Kekuasaan merupakan inti dari penyelenggaraan Negara agar Negara dalam keadaan bergerak (de staat in beweging) sehingga Negara itu dapat berkiprah, bekerja, berkapasitas, berprestasi, dan berkinerja melayani warganya, sehingga negara itu harus diberi kekuasaan. Kekuasaan adalah kemampuan seseorang atau sekelompok orang manusia untuk mempengaruhi tingkah laku seseorang atau kelompok lain sedemikian rupa sehingga tingkah laku itu sesuai dengan keinginan dan tujuan dari orang atau Negara.7

Salah satu bentuk kewenangan tersebut diantaranya adalah pengaturan dalam bidang pertambangan. Kegiatan pertambangan tidak saja diberikan kepada BUMN, BUMD maupun swasta, tapi juga diberikan kepada penduduk setempat. Penduduk setempat dapat melakukan kegiatan pertambangan dengan cara mengajukan izin pertambagan terlebih dahulu kepada pemerintah melalui pemerintah daerah setempat. Izin pertambangan tersebut sebagai payung hukum bagi penduduk/masyarakat maupun korporasi setempat untuk melakukan kegiatan pertambangan, atau dikenal dengan sebutan pertambangan rakyat.

Undang-undang tentang pertambangan mineral dan batu bara merupakan instrumen penting bagi pemerintah pusat dan daerah dalam melakukan ekselerasi dalam bidang pertambangan. Bagi pemerintah darah, payung hukum tersebut selanjutnya ditindak lanjuti dengan pembuatan produk hukum daerah terutama mengenai pengaturan pertambangan. Harmonisasi payung hukum tersebut untuk memberikan perlindungan hukum dan penguatan kelembagaan ditingkat daerah, agar proses kegiatan dalam bidang pertambangan yang dilakukan oleh masyarakat, perseorangan dan atau korporasi selaras dengan kehendak dan tujuan sebagaimana yang diatur dalam peraturan perundang-undangan. Pembentukan dan penguatan regulasi untuk memberikan perlindungan smua pihak yang ada kaitannya dalam bidang pertambangan. Masyarakat/rakyat, perseorangan maupun korporasi yang langsung bersentuhan dengan aktipitas pertambangan tersebut dilindungi oleh hukum.

Kewenangan pemerintah daerah dalam hal penerbitan izin pertambangan rakyat tersebut berkenaan dengan peruntukan, pemanfaatan, pengawasan dan penertiban. Dalam hal ini pemerintah daerah memberikan peruntukan kepada pemegang hak pertambangan rakyat dengan memperhatikan segala aspek yang ada di daerah. Aspek pertimbangan yang dijadika rujukan adalah peraturan perundang-undangan dalam bidang pertambangan, asaz-asaz umum pemerintahan yang baik, aspek ekonomi, kesehatan dan lingkungan hidup.

Salah salah satu bentuk implementasi kekuasaan dalam pelaksanaan pemerintah daerah yaitu kewenangan dalam pengaturan dan peruntukan izin pertambangan rakyat yang ada didaerah. Penyelenggaraan kewenangan dalam penyelenggaran otonomi daerah terutama dalam hal pertambangan rakyat akan berjalan dengan baik jika menerapkan prinsip-prinsip good governance. 8

6 . Sarkawi. (2013). Hukum Administrasi Negara. Mataram. Psutaka Bangsa.

Hlm. 41

$7 \quad$. Ibid.

8 . Sirajuddin dkk. (2016). Hukum Administrasi Pemerintahan Daerah; Sejarah, Asas, Kewenangan, dan pengawasan Peneyelnggaraan Pemerintahan Daerah. Malam. Setara 
Wilayah yang dapat ditetapkan sebagai wilayah pertambangan adalah wilayah yang memiliki kretirea adanya:9

a. Ketersediaan bahan tambang baik mineral maupun batu bara

b. Pemenuhan dan ketersediaan kekayaan alam lain, baik padat maupun cair

Upaya pemerintah dalam melakukan penataan pertambangan rakyat dilakukan dengan berbagai pertimbangan berdasarkan norma-norma hukum yang berlaku. Pengaturan tersebut untuk memberikan singkronisasi dan menjaga hubungan keberlangsungan pengelolaan sumberdaya alam yang ada untuk meningkatkan pendapatan daerah. Selain itu, pengaturan tersebut untuk menjaga hak masyarakat lainnya terhadap lingkungan hidup dan keberlangsungan kehidupan hayati yang lainnya.

1. Perencaan Wilayah Pertambangan

Perencanaan wilayah pertambangan merupakan proses, perbuatan atau cara merencanakan atau menyusun wilayah pertambangan. Perencanaan wilayah pertambangan disusun, melalui tahapan-tahapan sebagai berikut:

\section{a. Pendataan Potensi Tambang}

Pendataan potensi tambang dilakukan untuk melihat sebaran wilayah yang akan dilakukan penambangan. Sebaran wilayah penambangan ini digunakan untuk membuat sket/gambar/ petadaearah/wilayah akan dilakukan penambangan. Penentuan sebaran wilayah tersebut dilakukan dengan cara turun langsung kelapangan atau kelokasi yang telah ditentukan untuk melihat langsung, pengambilan sampel untuk selanjutnya diteliti sebelum proses kegiatan penambangan dilakukan oleh masyarakat. Kegiatan ini dilakukan untuk memperoleh informasi riil tentang aktipitas pertambagan, selanjutnya akan disusun rencana strategis, serta rencana kerja dengan membuat petunjuk teknis dan petunjuk pelaksaan pertambangan.

\section{b. Menentukan Lokasi Penambangan}

Penentuan lokasi penambangan ini dilakukan dengan photo satelit di wilayah yang sudah ditetapkan menjadi kawasan pertambangan. Pemetaan dengan media photo satelit tersebut selenjutnya dituangkan dalam bentuk gambar wilayah/ denah atau dalam sebutan lain dikenal dengan sebutan peta lokasi pertambangan. Pembuatan dan penentuan peta lokasi pertambangan tersebut dibutuhkan untuk menentukan batas wilayah yang boleh dilakukan penambangan. Penentuan dan pembagian tersebut diperuntukkan sesuai dengan keperluan dalam bidang pertambangan, seperti dalam hal penentuan wilayah usaha pertambangan, wilayah pertambangan rakyat maupun wilayah usaha penambangan yang dilakukan oleh pemerintah pusat serta dalam hal penentuan wilayah cadangan yang bersipat nasional.

\section{Menetapkan lokasi penambangan}

Penentuan atau penetapan lokasi penambangan dilakukan oleh pejabat yang berwenang dalam bidang terkait, seperti kementerian dalam bidang lingkungan hidup, mentri agraria, mentri kehutanan, mentri energi sumberdaya dan mineral serta mentri bidang pertanian. Koordinasi kementrian dilakuan dengan kepala daerah yang ada wilayah pertambangannya. Kementrian terkait selanjutknya mengumpulkan semua imformasi yang bersumber dari daerah setiap daerah provinsi. Daerah provinsi terlebih dahulu melakukan koordinasi dengan Bupati/ Walikota, selanjutnya diputuskan secara bersama ditingkat daerah.

Setelah dilakukan koordinasi mentri terkait dengan kepala daerah, selanjutnya dilakukan tahapan berikutnya, diantaranya dalam hal penentuan wilayah pertambangan dan wilayah pertambangan rakyat. Hasil dari penentuan lokasi ini selanjutnya akan dituangkan dalam

Press. Hlm. 5.

9 . Gatot Supramono.(2012). Hukum Pertambangan Mineral Dan Batubara Di Indonesia, Jakarta: Rineka Cipta. hlm. 25. 
bentuk keputusan tentang pemberian izin pertambagan. Setelah izin penambangan rakyat keluar, maka tahap berikutnya yang berkaitan dengan penambangan rakyat adalah sebagai berikut:

1. Eksplorasi Daerah Pertambangan

Walaupun pada waktu melakukan penetapan wilayah pertambangan sudah terdapat data peta potensi mineral dan/atau batubara, pejabat yang berwenang menetapkan wilayah usaha pertambangan dapat juga melakukan kegiatan eksploarasi untuk memperoleh data dan informasi.

Data dan informasi hasil eksplorasi kemudian harus diolah menjadi peta potensi / cadangan mineral dan/atau batubara yang minimal memuat sebaran potensi/ cadangan mineral dan/atau batubara. Peta potensi/cadangan mineral dan/atau batubara dibuat dalam bentuk lembar peta dan digital dan digunakan untuk menyusun rencana wilayah pertambangan rakyat (WPR).

2. Menyiapkan peta lokasi tambang rakyat

Penyiapan lokasi penambangan rakyat dilakukan berdasarkan petunjuk pada saat dilakukan proses pembuatan petalokasi wilayah penambangan. Pembuatan lokasi wilayah penambangan didasarkan pada hasil penelitian dan pengkajian yang dilakukan pada tahap awal, terutama untuk melihat kandungan atau ketersediaan bahan mineral atau batu bara yang akan dilakukan proses penambangan. Lokasi wilayah yang akan dilakukan penambangan oleh rakyat atau tambang rakyat, setidaknya harus memenuhi persyaratan sebagaimana disebutkan dalam Peraturan Pemerintah Nomor 22 Tahun 2010 tentang Wilayah Pertambangan.

3. Izin Wilayah Pertambangan Rakyat

Setiap masyarakat, baik individu, kelompok masyarakat maupun kelompok koperasi dapat mengajukan izin pertambangan rakyat. Izin pertambangan tersebut selajutnya diajukan oleh masing-masing pihak yang ada kepentingannya dengan pertambangan rakyat kepada pemerintah daerah. Pengajuan izin tersebut setidaknya telah melalui beberapa tahapan diantaranya adalah penentuan wilayah atau lokasi yang akan dijadikan lokasi pertambangan. Setelah dilakukan pemetaan lokasi sebaran posisi penambangan yang akan dilakukan oleh rakyat, selanjutnya pemerintah daerah menyiapkan regulasi berkenaan dengan pemberian izin penambangan yang akan dilakuka oleh rakyat. Izin usaha penambangan atau dikenal dengan sebutan IUP diberikan oleh Menteri, gubernur, atau bupati/walikota sesuai dengan kewenangannya berdasarkan permohonan yang diajukan oleh: badan usaha, koperasi, dan perseorangan. Sedangkan IPR (izin pertambangan rakyat) diberikan oleh bupati/walikota berdasarkan permohonan yang diajukan oleh penduduk setempat, baik orang perseorangan maupun kelompok masyarakat dan/atau koperasi.

Tahapan pengajuan permohonan izin pertambanagan dilakukan dengan terlebih dahulu mengajukan surat permohonan kepada pemerintah daerah setempat (bupati/walikota). Pengajuan surat permohonan tersebut disertai dengan materai dan surat rekomendasi dari kepala desa/lurah dan atau rekomendasi dari kepala adat setempat untuk mendapatkan skala prioritas untuk mendapatkan izin pertambangan rakyat tersebut.

Setelah pengajuan surat permohonan, ada syarat lain lagi yang harus dipenuhi oleh pemohon untuk mendapatkan izin pertambangan rakyat. Adapun syarat tersebut sebagai berikut:

A. Syarat administratif

Administratif merupakan rangkaian pengumpulan atau pengadministrasian setiap proses dalam suatu kegiatan dalam bentuk administrasi. Dalam tahap atau proses kegiatan administrasi ini, kepala daerah dalam kapasitasnya untuk memberikan izin pertambangan rakyat, maka harus memperhatikan syarat-syarat yang diajukan oleh pemohon. Adapun syarat administrasi yang dimaksud diantaranya adalah: 
a. Orang perseorangan

Syarat administratif pengajuan izin pertambangan rakyat yang di mohonkan oleh orang perseoragan berupa:

1. surat permohonan

2. kartu tanda penduduk

3. komoditas tambang yang dimohon dan

4. surat keterangan dari kelurahan/desa setempat

b. Masyarakat atau gabungan kelompok masyarakat

Syarat administratif pengajuan izin pertambangan rakyat yang di mohonkan oleh masyarakat atau gabungan kelompok masyarakat:

1. surat permohonan

2. komoditas tambang yang dimohon dan

3. surat keterangan dari kelurahan/desa setempat

c. Koperasi

Syarat administratif pengajuan izin pertambangan rakyat yang di mohonkan oleh koperasi diantaranya adalah sebagai berikut:

1. surat permohonan

2. Nomor Pokok Wajib Pajak (NPWP)

3. akte pendirian koperasi yang telah disahkan oleh pejabat yang berwenang

4. komoditas tambang yang dimohonkan dan

5. surat keterangan dari kelurahan/desa setempat

B. Syarat teknis fisik kewilayahan

Syarat teknis pisik kewilayahan merupakan syarat yang berkaitan dengan persoalan atau masalah teknisi yang bersifat tenik, misalnya berkenaan dengan cara pengambilan, pengangkutan, pengolahan bahan tambang dan penjualan. Pengajuan izin pertambangan sebagai syarat teknis pisik kewilayahan setidaknya memuat hal-hal sebagai berikut:

1. Kedalamansumurpengoborantambangpadapengajuanizinpertambanganrakyatmaksimal 25 (dua puluh lima) meter

2. Menggunakan pompa mekanik, penggelundungan atau permesinan dengan jumlah tenaga maksimal 25 (dua puluh lima) horse power untuk 1 (satu) IPR; dan

3. Tidak diperkenankan/tidak diperbolehkan menggunakan alat berat dan bahan peledak

C. Syarat ekonomi atau finansial

Syarat ekonomi atau syarat finansial adalah syarat yang berkenaan dengan ketersediaan dan atau kemampuan keuangan, yaitu berkaitan dengan laporan keuangan. Laporan keuangan yang dimaksud adalah laporan penggunaan keuangan selama 1 (satu) tahun terakhir. Syarat kemampuan finansial ini ditujukan hanya kepada lembaga koperasi yang akan mengajukan proses penerbitan izin pertambanga rakyat, jika peruntukannya bukan untuk pengajuan izin pertambangan rakyat maka syarat kemampuan finansial tersebut dinyatakan tidak berlaku atau tidak diperlukan.

Syarat-syarat sebagaimana disebutkan diatas, maka Bupati/Walikota selanjutnya melakukan pemeriksaan terhadap semua kelengkapan tersebut, jika dalam pemeriksaan yang dilakukan ditemukan adanya kekurangan syarat tersebut, Bupati/Walikota dapat menolak dan tidak menerbitkan izin pertambangan rakyat yang diajukan oleh para pihak. Izin pertambangan rakyat tersebut baru bisa diterbitkan oleh Bupati/Walikota jika semua syarat yang diajukan oleh para pihak dinyatakan lengkap semua. 


\section{Dampak Pertambangan Rakyat}

Setiap proses kegiatan yang kita lakukan sudah barang tentu akan memberikan dampak bagi pihak yang melakukannya. Dampak tersebut berproses dengan sendirinya, sejalan waktu terhadap semua akitipitas dalam kehidupan manusia. Dalam perjalanan waktu, hasil dari setiap kegiatan tersebut akan melahirkan dampak yang baik (positif) dan maupun tidak baik (negatif). Demikian juga dalam bidang tertambangan yang dilakukan oleh rakyat. Kegiatan pertambangan yang dilakukan oleh rakyat sudah barang tentu akan memberikan dampak hasil dari kegiatan tersebut. Dampak dari kegiatan tersebut bisa dalam bentuk dampak positif dan bisa juga dalam bentuk dampak negatif.

Dampak positif dari kegiatan pertambagan rakyat dapat kita lihat diantaranya sebagai berikut:

1. Adanya peningkatan taraf kesejahteraan hidup masyakat setempat

Pertambangan yang dilakukan oleh rakyat atau masyarakat atau kelompok masyarakat sudah barang tentu memberikan dampak posisti dari segi ekonomi. Dengan adanya pertambangan rakyat diwilayah setempat, setidaknya ada peningkatan ekonomi rakyat kecilberupabertambahnyakios-kiosberjualankebetuhanhidup,meningkatkan pendapatan rumah tangga, meningkatnya pemenuhan kebutuhan dasar hidup masyarakat di lingkar tambang.

2. Peningkatan PAD dan PADes

Pemberianizinpertambanganrakyatberdampakpadapenambahanpenerimaan pendapatan daerah dan desa. Bagi pemerintah daerah dan pemerintah desa dapat menarik retribusi terhadap kegiatan pertambangan yang dilakukan oleh seorang atau kelompok masyarakat maupun koperasi.

3. Penyerapan tenaga kerja

Kegiatan pertambangan tidak bisa dijalankan sendiri oleh sesorang, melainkan butuh beberapa orang untuk membantu jalanya proses kegiatan pertambangan, misalnya penyewaan alat angkut bahan galian menuju lokasi ahir penggilingan dan lain sebaginya.

4. Megurangi tindak kejahatan dalam lingkungan masyarakat

Denganadanyakegiatanpertambanganrakyat,setidaknyabebanhidupmasyrakatberkurang, dari sebelumnya banyak pengguran yang berdampak pada maraknya kasus pencurian karna tidak adanya pekerjaan, begitu adanya izin pengelolaan dan pemanfaatan pertambangan rakyat,penyakityang seringmeresahkanmasyarakat tersebutberangusur-angsurberkurang karna adanya lapangan pekerjaan baru yang menjanjikan perbaikan masa depan keluarga.

Selain dampak postif dari kegiatan pertambangan tersebut, ada juga dampak negatifnya. Adapun beberapa dampak nehatif dari kegiatan pertambangan rakyat tersebut diantaranya adalah:

1. Terjadinya pencemaran lingkungan

2. Gangguan pada kesehatan terhadap penggunaan bahan kimia yang berlebihan

3. Rusaknya tatanan ekosistem rantai makan

4. Pencemaranudaraakibatpenggunaanalatpenggelinganyang tidaksesuai standarkesehatan pertambangan.

Denga melihat dampak yang ada, pemerintah daerah dapat melakukan langkah-langkah dalam melakukan penertiban pertambangan rakyat dengan beberapa langkah sebagai berikut:

1. Pengetatan pemberian izin pertambangan rakyat, baik kepada perorangan maupun pada kelompok masyarakat

2. Melakukanedukasi/penyuluhansecaraberkalakepadamasyarakatakanpentinyakesadaran bersama terhadap lingkungan hidup

3. Melakukan pemetaan dengan baik terhadap lokasi izin pertambanga rakyat 
4. Mencabut izin pertambangan rakyat

5. Menerapkan sanksi denda dan sanksi pidana bagi pelanggar pertambangan rakyat yang dilakukan tampa izin dari pemerintah daerah.

\section{KESIMPULAN}

Pemerintah daerah selaku pemegang hak terhadap pertambangan rakyat, perlu melakukan penataan secara terstruktur, sistematis dan terarah kepada semua pihak yang berkepentingan terhadap pertambagan rakyat, dengan mempertimbangan aspek hukum serta asaz-asaz umum pemerintahan yang baik. Dalam melakukan penataan pertambangan rakyat, pemeritah daerah dapat memberikan atau menerbitkan izin pertambangan rakyat sesuai dengan ketentuan peraturan perundang-undangan yang berlaku, terutama dalam hal penerbitan izin lokasi pertambangan rakyat. Selain itu, sebelum menerbitkan izin pertambangan rakyat tersebut, pemerintah daerah terlebih dahulu melakukan edukasi kepada masyarakat tentang dampak pertambangan rakyat, baik itu dampak postif maupun dampak negatif. Dalam hal terjadi pelanggaran terhadap izin pertambangan, pemerintah daerah dapat melakukan langkakah-langkah berupa pembekuan atau penarikan atau pencabutan izin pertambanga rakyat, menerapkan sanksi uang gati rugi atau dapat menerapkan sanksi pidana sesuai dengan peraturan perundang-undangan yang berlaku.

\section{DAFTAR PUSTAKA}

Amiruddin dan Zainal Asikin.(2004). Pengantar Metode Penelitian Hukum, Cetakan Kedua, Jakarta : PT. Raja Grafindo.

Rahman, arif; ade mulada, Diman. (2018). Kajian Yuridis Tentang Keberadaan Pertambangan Rakyat, Jurnal Jatiswara, v.33, nov.

Gatot Supramono.(2012). Hukum Pertambangan Mineral Dan Batubara Di Indonesia, Jakarta: Rineka Cipta.

M. Saleh dkk. (2015). Aspek Yuridis Terhadap Pelaksanaan Pertambangan Rakyat Berdasarkan UU No 4 Tahun 2009 (Studi Di Kab.Sumbawa Barat), Jurnal Jatiswara, v.30, Juli.

Salim HS. (2006). Hukum Pertambangan di Indonesia, Jakarta, Raja Grafindo Persada. -.(2012). Hukum Pertbangan Mineral dan Batu Bara. Jakarta. Sinar Grafika.

Sarkawi. (2013). Hukum Administrasi Negara. Mataram. Psutaka Bangsa.

Sirajuddin dkk. (2016). HukumAdministrasi Pemerintahan Daerah; Sejarah, Asas, Kewenangan, dan pengawasan Peneyelnggaraan Pemerintahan Daerah. Malam. Setara Press. 